\title{
PEMANFAATAN MEDIA TEKA TEKI SILANG UNTUK MENINGKATKAN AKTIVITAS DAN HASIL BELAJAR PESERTA DIDIK DI SMK SMTI PADANG
}

\author{
Masna Ainul \\ Sekolah Menengah Kejuruan SMTI Padang, Indonesia \\ email: masnabachtiar@gmail.com
}

\begin{abstract}
Learning media is something that can be used to convey information between individuals and individuals or groups, so that media involvement in learning can increase student learning activities and outcomes. The purpose of this study was to determine the use of crossword puzzles to increase students' activities and learning outcomes. This research is Classroom Action Research using two research cycles. This research was conducted at the Vocational High School SMTI Padang with the subject of class XII.2 group A students totaling 18 people. From the data obtained, it is concluded that the use of crossword puzzle media can increase activity and learning outcomes. In the learning process students can develop students' thinking power in understanding Process Control lessons and increase students' interest in exploring subjects.
\end{abstract}

Keywords: learning media, crossword puzzles, learning activities, learning outcomes

Abstrak: Media pembelajaran adalah suatu hal yang dapat digunakan untuk menyampaikan informasi antara individu dengan individu maupun kelompoknya, sehingga keterlibatan media dalam pembelajaran dapat meningkatkan aktivitas dan hasil belajar peserta didik. Tujuan penelitian ini adalah untuk mengetahui penggunaan media teka teki silang untuk meningkatkan aktivitas dan hasil belajar peserta didik. Penelitian ini adalah Penelitian Tindakan Kelas dengan menggunakan dua siklus penelitian. Penelitian ini dilakukan di Sekolah Menengah Kejuruan SMTI Padang dengan subjek peserta didik kelas XII.2 group A berjumlah 18 orang. Dari data yang diperoleh disimpulkan bahwa penggunaan media teka teki silang dapat meningkatkan aktivitas dan hasil belajar. Dalam proses pembelajaran siswa dapat mengembangkan daya pikir siswa dalam memahami pelajaran Kontrol Proses dan meningkatkan minat peserta didik dalam mendalami mata pelajaran.

Kata Kunci : media pembelajaran, teka teki silang, aktivitas belajar, hasil belajar

Copyright (c) 2021 The Authors. This is an open access article under the CC BY-SA 4.0 license (https://creativecommons.org/licenses/by-sa/4.0/)

\section{PENDAHULUAN}

Pendidikan adalah usaha sadar dan terencana untuk mewujudkan suasana belajar dan proses pembelajaran agar peserta didik secara aktif mengembangkan potensi dirinya untuk memiliki kekuatan spiritual keagamaan, pengembangan diri, 
kepribadian, akhlak mulia, serta keterampilan yang dimiliki dirinya, masyarakat, bangsa dan Negara (Undang-undang Nomor 20 Tahun 2003 pasal 1, butir 1). Pendidikan memegang peranan penting untuk usaha meningkatkan kualitas sumber daya manusia untuk memecahkan persoalan yang dihadapai. Walaupun telah banyak usaha dilahirkan untuk meningkatkan kualitas jenjang pendidikan tersebut, namun kenyataan masih menunjukkan tanda-tanda belum terpenuhinya harapan.

Untuk mendukung tercapainya tujuan pendidikan, guru bertanggung jawab dalam menciptakan iklim pembelajaran yang kondusif mendorong dan memotivasi siswa untuk melakukan proses pembelajaran dalam rangka peningkataan keberhasilan dan gairah belajar peserta didik (Zein, 2016). Selanjutnya dikatakan pula, bahwa kualitas dan keberhasilan pembelajaran sangat dipengaruhi oleh kemampuan dan ketepatan guru dalam mempersiapkan perencanaan matang, pelaksanaan yang baik dan evaluasi secara komprehensif (Awal \& Sari, 2019). Sehingga diharapkan dalam proses pembelajran tercipta suasana yang aktif, kreatif dan menyenangkan untuk mencapai tujuan pembelajaran.

Namun demikian sampai saat ini dunia pendidikan masih didominasi oleh pandangan bahawa pengetahuan merupakan seperangkat fakta yang harus dihafal. Kelas sebagian besar masih berfokus pada guru sebagai sumber pengetahuan utama dalam strategi pembelajaran. Pada pembelajaran Kontrol Proses peserta didik terlihat kurang antusias, daya kreativitasnya rendah, dan peserta didik bersikap acuh tak acuh. Hal dimungkinkan karena strategi pembelajarannya kurang memiliki daya dukung terhadap aktivitas dan hasil belajar peserta didik.

Kontrol Proses merupakan salah satu mata pelajaran di Sekolah Menengah Kejuruan SMTI Padang yang dipelajari siswa kelas 12. Kompetensi Dasar yang ada pada mata pelajaran Kontrol Proses berdasarkan kurikulum 2013 yang terdiri dari kompetensi dasar ketrampilan dan kompetensi dasar pengetahuan. Seperti kebanyakan peserta didik di SMK SMTI Padang, untuk kompetensi dasar keterampilan lebih disukai karena merupakan aplikasi atau praktik dengan menggunakan peralatan, tetapi pada kompetensi dasar pengetahuan peserta didik kurang berminat. Hal ini disebabkan 
materi pelajaran yang komplek, sering dianggap sebagai pelajaran yang membosankan, banyak hafalan dan istilah asing.

Berdasarkan nilai pengetahuan Kontrol Proses pada kelas sebelumnya, nilai hasil belajar peserta didik masih banyak dibawah KKM. Selama ini guru menjelaskan materi sudah dengan baik dengan menggunakan metode ceramah dan tanya jawab. Namun peserta didik kurang aktif terlibat dalam proses pembelajaran, peserta didik hanya sekedar duduk diam sekedar mendengarkan penjelasan dan menjawab pertanyaan guru. Hal tersebut akan membuat siswa kurang memahami materi pelajaran, sehingga berdampak pada minat dan hasil belajar siswa yang rendah, terutama ranah kognitif (Meileni, Tastra, \& Riastini, 2017).

Untuk meningkatkan aktivitas dan hasil belajar peserta didik yang lebih baik dapat dilakukan beberapa perubahan dalam proses pembelajaran, dinataranya adalah penggunaan media permainan edukatif yang dapat menarik minat siswa dalam proses pemeblajaran, sehingga peserta didik termotivasi untuk mempelajari materi pelajaran teori/pengetahuan kontrol proses. Terdapat ragam media pembelajaran permainan edukatif yang dapat digunakan, salah satunya adalah media Teka Teki Silang (TTS).

Teka-teki silang adalah suatu permainan di mana kita harus mengisi ruangruang kosong (berbentuk kotak putih) dengan huruf-huruf yang membentuk sebuah kata berdasarkan petunjuk yang diberikan. Petunjuk biasanya dibagi ke dalam kategori "Mendatar" dan "Menurun" tergantung posisi kata-kata yang harus diisi (Nafi' \& Sulistiyo, 2013). Media Teka Teki Silang merupakan suatu pendekatan yang dikemas dalam bentuk permainan yang dapat merangsang daya pikir peserta didik dalam proses pembelajaran.

Teka-teki silang (TTS) merupakan permainan klasik yang memberikan pengaruh dalam kemampuan otak dan pengetahuan dalam menjadikan peserta didik aktif, menyenangkan, memunculkan semangat belajar, menumbuhkan rasa kreatifitas peserta didik, mengasah daya ingat peserta didik. Media tersebut bersifat fleksibel yang dapat digunakan di manapun tanpa ada penyesuaian khusus, serta dapat digunakan dalam kelompok besar dan kelompok kecil. Sebagai media visual Teka Teki Silang memiliki banyak keunggulan dalam proses pembelajaran diantaranya: dapat 
meningkatkan daya ingat siswa,menumbuhkan rasa kreatifitas peserta didik, meningkatkan antusias belajar, serta membuat proses belajar lebih menyenangkan (Lakoro, Eraku, \& Yusuf, 2020).

Penulis berharap dengan adanya penggunaan media pembelajaran Teka Teki Silang (TTS) pada mata pelajaran Kontrol Proses dapat meningkatkan aktivitas dan hasil belajar peserta didik. Sehubungan dengan maksud tersebut penelitian ini bertujuan untuk mengetahui pemanfaatan Media Teka Teki Silang dalam meningkatkan aktivitas dan hasil belajar peserta didik pada mata pelajaran Kontrol Proses di SMK SMTI Padang serta mengetahui kendala-kendala yang dihadapi.

\section{METODE}

Penelitian ini dilakukan dengan menggunakan metode Penelitian Tindakan Kelas (PTK). PTK adalah penelitian yang dilakukan oleh guru di dalam kelasnya sendiri melalui refleksi diri dengan tujuan untuk memperbaiki kualitas proses pembelajran di kelas, sehingga hasil belajar peserta didik dapat ditingkatkan. PTK dilakukan secara bertahap dan terus menerus. Peneliti menggunakan desain penelitian yang sesuai dengan desain yang digunakan oleh Kemmis dan Mc. Tanggart yaitu model spiral yang dimulai dengan perencanaan, tindakan, observasi, dan refleksi, kemudian mengadakan perencanaan kembali, yang dapat digambarkan sebagai berikut:

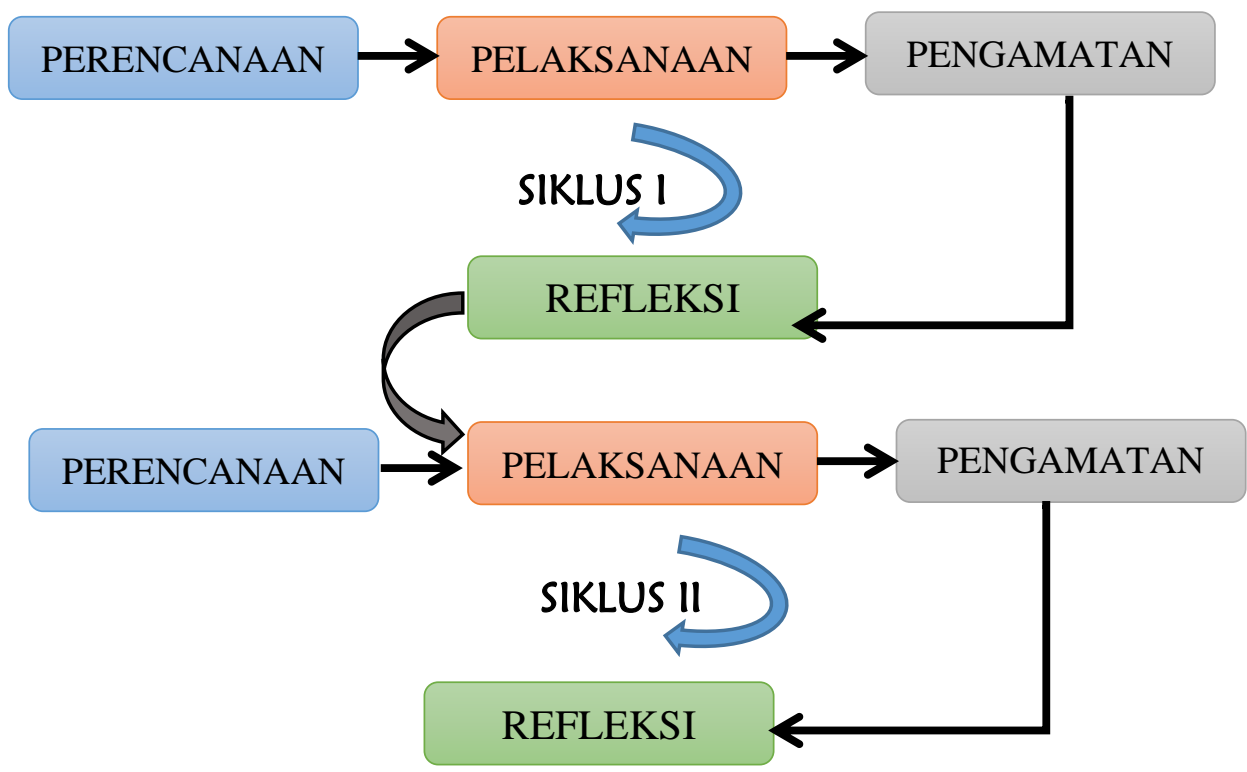

Gambar 1. Proses Penelitian Tindakan Kelas 
Teknik yang digunakan untuk mengumpulkan data pada penelitian ini, yaitu tes, observasi dan dokumentasi. Tes dilakukan dalam bentuk ulangan harian (post test) untuk mengukur peningkatan prestasi belajar siswa dalam menerima pembelajaran melalui media Teka Teki Silang.

Dilaksanakan setiap akhir siklus. Tes (post test), digunakan untuk mengetahui hasil belajar siswa, dilakukan evaluasi dalam bentuk post test pada akhir kegiatan pembelajaran. Observasi (pengamatan), digunakan oleh peneliti untuk memperoleh data aktifitas sisa dalam menerapkan pembelajaran, dan kinerja guru dalam menerapkan pembelajaran menggunakan media TTS. Observasi dalam penelitian ini dilakukan oleh guru selaku peneliti dengan menggunakan lembar observasi. Dokumentasi yang dilakukan peneliti dalam penelitian tindakan kelas yaitu menggunakan gambar (poto) yang diambil pada saat pelaksanaan penelitian yang dilakukan dari pertemuan pertama sampai pertemuan terakhir serta foto-foto yang mendukung kegiatan pelaksanaan penelitian. Tujuan dokumentasi yang dilakukan peneliti untuk mempermudah peneliti dalam membuktikan hasil penelitian yang dilaksanakan dengan sebenar-benarnya melalui lampiran berupa gambar (foto) dari kegiatan penelitian yang dilakukan.

Instrumen merupakan pengumpul data dalam penelitian. Tujuan dari penggunaan instrumen adalah untuk memudahkan peneliti dalam mengambil dan mengolah data. Instrumen penelitian yang digunakan untuk mengumpulkan data dalam penelitian ini adalah dengan lembar observasi dan soal tes. Lembar observasi digunakan untuk mengetahui proses berlangsungnya pembelajaran. Adapun soal tes digunakan untuk mengetahui pencapaian kompetensi peserta didik. Bentuk tes yang digunakan pada penelitian ini adalah tes objektif dan tes uraian yang berkaitan dengan materi kontrol proses.

Seorang siswa atau peserta didik dikatakan tuntas belajar secara individual jika telah mencapai nilai SKM 75, yang dihitung dengan rumus berikut:

$$
\text { Persentase }(\%)=\frac{\text { Jumlah siswa tuntas belajar }}{\text { Jumlah seluruh siswa }} \times 100 \%
$$


Hasil observasi proses pembelajaran adalah dengan menghitung jumlah skor pengamatan dengan teknik dan kriteria. Untuk mengetahui tentang kemampuan psikomotorik peserta didik dalam mengikuti prose pembelajaran Kontrol proses, maka penulis membuat 4 aspek pengamatan yang meliputi: kemampuan menyampaikan informasi, kemampuan memberikan pendapat/ide, kemampuan mengajukan pertanyaan, kemampuan mengajukan argumentasi. Untuk melihat kecendrungan tujuan penelitian digunakan interval persentase, terdapat lima kriteria yang digunakan untuk menentukan level aktivitas belajar peserta didik syah(2004:148) yaitu :

$$
\begin{array}{ll}
-80 \%-100 \% & =\text { sangat baik } \\
-70 \%-79 \% & =\text { baik } \\
-60 \%-69 \% & =\text { cukup } \\
-\leq 59 \% & =\text { kurang }
\end{array}
$$

Indikator keberhasilan dalam penelitian ini adalah apabila kemampuan peserta didik kelas XII.2 SMK SMTI Padang Tahun Pelajaran 2019/2020 dalam menyelesaikan soal-soal Kontrol Proses menggunakan media Teka Teki Silang yang ditandai dengan kriteria sebagai berikut:

1. Nilai rata-rata peserta didik mengalami peningkatan di atas 70 .

2. Ketuntasan belajar klasikal diatas $85 \%$.

3. Pencapaian hasil belajar siswa dikatakan tuntas belajar jika peserta didik memperoleh nilai yang sesuai dengan SKM yang telah ditentukan yaitu 75 .

\section{HASIL DAN PEMBAHASAN}

\section{Siklus 1}

Hasil observasi terhadap aktivitas peserta didik dalam proses pembelajaran dapat dilihat pada lampiran 9 dan 10 yang terangkum pada tabel 1 . 
Tabel 1. Hasil Observasi Aktivitas Peserta Didik Siklus I

\begin{tabular}{|c|c|c|c|c|c|}
\hline \multirow[t]{2}{*}{ No. } & \multirow{2}{*}{$\begin{array}{c}\text { Aktivitas Peserta } \\
\text { Didik }\end{array}$} & \multicolumn{2}{|c|}{ Pertemuan 1} & \multicolumn{2}{|c|}{ Pertemuan 2} \\
\hline & & Skor & $\begin{array}{c}\text { Persentase } \\
(\%)\end{array}$ & Skor & $\begin{array}{c}\text { Persentase } \\
(\%)\end{array}$ \\
\hline 1. & $\begin{array}{l}\text { Peserta didik aktif } \\
\text { dalam kelompok }\end{array}$ & 2,00 & 66,67 & 2,00 & 66,67 \\
\hline 2. & $\begin{array}{l}\text { Peserta didik aktif } \\
\text { menjawab pertanyaan }\end{array}$ & 1,00 & 33,33 & 1,12 & 37,25 \\
\hline 3. & $\begin{array}{l}\text { Peserta didik aktif } \\
\text { mengajukan } \\
\text { pertanyaan }\end{array}$ & 1,35 & 45,10 & 1,35 & 45,10 \\
\hline 4. & $\begin{array}{l}\text { Peserta didik aktif } \\
\text { membaca sumber } \\
\text { belajar }\end{array}$ & 1,71 & 56,86 & 2,18 & 72,55 \\
\hline 5. & $\begin{array}{l}\text { Peserta didik aktif } \\
\text { merespon pernyataan } \\
\text { dari teman }\end{array}$ & 1,18 & 39,22 & 1,71 & 56,86 \\
\hline & Jumlah & 7,24 & 48,24 & 8,35 & 55,65 \\
\hline
\end{tabular}

Tabel 1 menunjukkan bahwa aktivitas belajar peserta didik pada siklus I pada pertemuan 1 meningkat pada pertemuan 2. Hasil yang terlihat pada tabel 1 menunjukkan bahwa aktivitas belajar peserta didik termasuk kategori kurang $(\leq 59 \%)$. Hal terlihat pada kurangnya antusiasnya peserta didik dalam proses pembelajaran. Hasil belajar pada siklus I dapat dilihat pada hasil tes yang diberikan pada akhir pelaksanaan kegiatan siklus I. Pada siklus I masih banyak perserta didik yang belum tuntas atau nilai yang masih di bawah standar ketuntasan minimum. Berdasarkan data yang diperoleh (lampiran 13) didapatkan masih banyak peserta didik yang mempunyai nilai ketuntasan di bawha SKM yaitu 75.

Tabel 2 menunjukkan hasil belajar peserta didik pada siklus I, dimana ketuntasan klasikal pada siklus I sebesar 29,42\%. Berdasarkan tabel 3, ketuntasan klasikal pada siklus I termasuk kategori sangat rendah (20\% - 36\%).

Edusaintek: Jurnal Pendidikan, Sains dan Teknologi Vol. 8 (1) 2021 | 41 
Tabel 2. Hasil Belajar Peserta Didik Siklus I

\begin{tabular}{cccc}
\hline No. & Hasil Tes & Nilai & Ketuntasan Klasikal \\
\hline $\mathbf{1}$ & Nilai Tertinggi & 83 & $29,41 \%$ \\
\hline $\mathbf{2}$ & Nilai Terendah & 65 & \\
\hline $\mathbf{3}$ & Nilai Rata-rata & 71,65 \\
\hline
\end{tabular}

Tabel 3. Kategori Tingkat Ketuntasan Klasikal Peserta didik Siklus I

\begin{tabular}{clcc}
\hline No. & Kategori & Rentang Skor & Ketuntasan Klasikal \\
\hline $\mathbf{1}$ & Sangat tinggi & $85 \%-100 \%$ & $\begin{array}{c}29,41 \% \\
\text { (kategori sangat } \\
\text { rendah }\end{array}$ \\
\hline $\mathbf{2}$ & Tinggi & $69 \%-84 \%$ & \\
\hline $\mathbf{3}$ & Cukup & $53 \%-68 \%$ & \\
\hline $\mathbf{4}$ & Rendah & $37 \%-52 \%$ & \\
\hline $\mathbf{5}$ & Sangat Rendah & $20 \%-36 \%$ & \\
\hline
\end{tabular}

\section{Refleksi}

Berdasarkan hasil observasi pada siklus I pertemuan 1 dan pertemuan 2, proses pembelajaran yang berlangsung belum efektif, hal ini ditunjukkan oleh aktivitas peserta didik dalam pembelajaran sebesar 48,24\% di pertemuan pertama dan 55,69\% di pertemuan kedua. Pada siklus I, penggunaan media teka teki silang dalam proses pembelajaran dapat diterima dengan baik oleh peserta didik, namun masih terdapat kekurangan-kekurangan yang harus diperbaiki agar proses pembelajaran dapat berlangsung dengan baik. Beberapa hal yang diamati pada pelaksanaan siklus I adalah

1. Masih banyak peserta didik yang tidak memiliki sumber belajar

2. Keaktifan dalam mengikuti proses pembelajaran masih belum merata

3. Peserta didik mempunyai antusias yang cukup baik dalam kegaitan pembelajaran, hal ini terlihat saat mengisi teka teki silang yang diberikan oleh guru.

Berdasarkan uraian diatas peneliti dalam hal ini guru mata pelajaran memberikan nilai lebih kepada peserta didik yang mempersiapkan sumber belajar sehingga memotivasi peserta didik untuk mencari dan memiliki sumber-sumber 
belajar. Sedangkan peserta didik yang kurang aktif diberikan kesempatan lebih banyak bertanya, jika ada peserta didik yang terlihat bertanya kepada peserta didik yang lain, guru langsung merespon peserta didik untuk menanyakan langsung kepada guru. Hal ini agar peserta didik mempunyai keberanian mengajuan pertanyaan langsung kepada guru mata pelajaran.

\section{Siklus II}

Berdasarkan hasil analisis data pada kegiatan siklus II, pembelajaran Kontrol Proses dengan menggunakan teka teki silang menunjukkan hasil baik dan menuaskan. Gru mampu mengatasi kendala-kendala yang ada pada setiap tindakan sehingga pada siklus II ini kegiatan pembelajaran dapat dilaksanakan dengan baik.

Tabel 4 menunjukkan aktivitas pembelajaran meningkat dari pertemuan pertama ke pertemuan kedua. Pada pertemuan pertama aktivitas peserta didik meningkat menjadi 87,06 \% jika dibandingkan dengan aktivitas belajar pada siklus I, begitu juga pada pertemuan kedua aktivitas belajar peserta didik dengan menggunakan media teka teki silang meningkat sebesar 92,04\%. Persentase peningkatan altivitas belajar ini termasuk kategori sangat baik.

Tabel 4. Hasil Observasi Aktivitas Peserta Didik Siklus II

\begin{tabular}{|c|c|c|c|c|c|}
\hline \multirow[t]{2}{*}{ No. } & \multirow{2}{*}{$\begin{array}{c}\text { Aktivitas Peserta } \\
\text { Didik }\end{array}$} & \multicolumn{2}{|c|}{ Pertemuan 1} & \multicolumn{2}{|c|}{ Pertemuan 2} \\
\hline & & Skor & $\begin{array}{c}\text { Persentase } \\
\text { (\%) }\end{array}$ & Skor & $\begin{array}{c}\text { Persentase } \\
\text { (\%) }\end{array}$ \\
\hline 1. & $\begin{array}{l}\text { Peserta didik aktif } \\
\text { dalam kelompok }\end{array}$ & 2,71 & 90,20 & 2,88 & 96,08 \\
\hline 2. & $\begin{array}{l}\text { Peserta didik aktif } \\
\text { menjawab } \\
\text { pertanyaan }\end{array}$ & 2,41 & 80,39 & 2,47 & 82,35 \\
\hline 3. & $\begin{array}{l}\text { Peserta didik aktif } \\
\text { mengajukan } \\
\text { pertanyaan }\end{array}$ & 2,35 & 78,43 & 2,71 & 90,20 \\
\hline 4. & $\begin{array}{l}\text { Peserta didik aktif } \\
\text { membaca sumber } \\
\text { belajar }\end{array}$ & 2,82 & 94,12 & 2,94 & 98,04 \\
\hline
\end{tabular}

Edusaintek: Jurnal Pendidikan, Sains dan Teknologi Vol. 8 (1) $2021 \mid 43$ 


\begin{tabular}{llllll}
\hline 5. $\begin{array}{l}\text { Peserta didik aktif } \\
\text { merespon } \\
\text { pernyataan dari } \\
\text { teman }\end{array}$ & 2,76 & 92,12 & 2,94 & 98,04 \\
& Jumlah 13,06 & 87,06 & 13,94 & 92,94 \\
\hline
\end{tabular}

Tabel 5 menunjukkan adanya peningkatan hasil belajar pada siklus II juga mengalami peningkatan. Hasil belajar peserta didik mengalami peningkatan dapat dilihat dari persentase ketuntasan klasikal pada siklus II sebesar 94,12\%. Pada tes yang dilaksanakan pada siklus II, peserta didik sudah banyak yang mendapatkan nilai di atas SKM yang ditetapkan yaitu 75. Berdasarkan kategori pada tabel 6, hasil belajar peserta didik pada tes akhir adalah kategori sangat tinggi.

Tabel 5. Hasil Belajar Peserta Didik Siklus II

\begin{tabular}{cccc} 
No. & Hasil Tes & Nilai & $\begin{array}{c}\text { Ketuntasan } \\
\text { Klasikal }\end{array}$ \\
\hline $\mathbf{1}$ & Nilai Tertinggi & 95 & $94,12 \%$ \\
\hline $\mathbf{2}$ & Nilai Terendah & 70 & \\
\hline $\mathbf{3}$ & Nilai Rata-rata & 85 & \\
\hline
\end{tabular}

Tabel 6. Kategori Tingkat Ketuntasan Klasikal Peserta didik Siklus II

\begin{tabular}{|c|c|c|c|}
\hline No. & Kategori & Rentang Skor & $\begin{array}{c}\text { Ketuntasan } \\
\text { Klasikal }\end{array}$ \\
\hline 1 & Sangat tinggi & $85 \%-100 \%$ & \multirow{5}{*}{$\begin{array}{c}94,12 \% \\
\text { (kategori sangat } \\
\text { tinggi) }\end{array}$} \\
\hline 2 & Tinggi & $69 \%-84 \%$ & \\
\hline 3 & Cukup & $53 \%-68 \%$ & \\
\hline 4 & Rendah & $37 \%-52 \%$ & \\
\hline 5 & Sangat Rendah & $20 \%-36 \%$ & \\
\hline
\end{tabular}

Edusaintek: Jurnal Pendidikan, Sains dan Teknologi Vol. 8 (1) 2021 | 44 


\section{Refleksi}

Berdasarkan hasil analisis pada kegiatan siklus II, pembelajaran Kontrol Proses dengan menggunakan media teka teki silang menunjukkan hasil yang baik dan memuaskan. Guru mampu mengatasi kendala-kendala yang ada pada setiap tindakan sehingga pada siklus II ini kegiatan pembelajaran dapat dilaksanakan dengan sangat baik. Hal ini dapat terlihat pada aktivitas peserta didik, antuasisme peserta didik dalam pembelajaran di kelas yang semakin baik, peserta didik sudah terbiasa mencari sumbersumber belajar sendiri serta suasana belajar yang menjadi interaktif. Peserta didik yang tidak punya keberanian mengajukan pertanyaan, menjadi percaya diri dalam mengajukan pertanyaan dan menjawab pertanyaan baik yang diajukan oleh guru maupun yang datang dari peserta didik. Aktivitas peserta didik juga mengalami peningkatan dalam hal merespon teman sejawat dan bekerjasama dalam kelompok. Peserta didik yang semulanya acuh saja pada teman sejawat menjadi peduli dan merespon setiap peserta didik yang lain mengajukan pertanyaan. Demikian juga dengan hasil belajar peserta didik yang mengalami peningkatan. Hal ini karena peserta didik sudah terbiasa dengan istilah-istilah asing yang banyak tedapat pada materi pembelajran. Dengan media teka teki silang, peserta didik dilatih untuk mengingat materi pelajaran, sehingga pada saat menjawab soal tes yang diberikan peserta didik sudah mudah mengingatnya.

Pembahasan

Berdasarkan data yang diperoleh (gambar 1) dari siklus I dan siklus II menunjukkan adanya peningkatan aktivitas belajar peserta didik di dalam kelas selama proses pembelajaran. Berdasarkan data yang diperoleh dari hasil ujian peserta didik yang diberikan pada akhir setiap siklus menunjukkan bahwa hasil belajar secara klasikal sudah mencapai target yaitu sekurang-kurang $80 \%$ peserta didik yang tuntas SKM dan mengalami peningkatan pada siklus II sebesar 64,71\%. Banyaknya peserta didik yang tuntas SKM pada sikus II berpengaruh juga pada peningkatan nilai rata-rata kelas. Nilai rata-rata kelas pada siklus I yaitu $71,65 \%$ dan mengalami peningkatan pada siklus II yaitu 85\%. Dari analisis data didapatkan bahwa rata-rata kelas sudah mencapai 
target yaitu sekurang-kurangnya 80 untuk nilai rata-rata kelas, seperti terlihat pada gambar 2 .

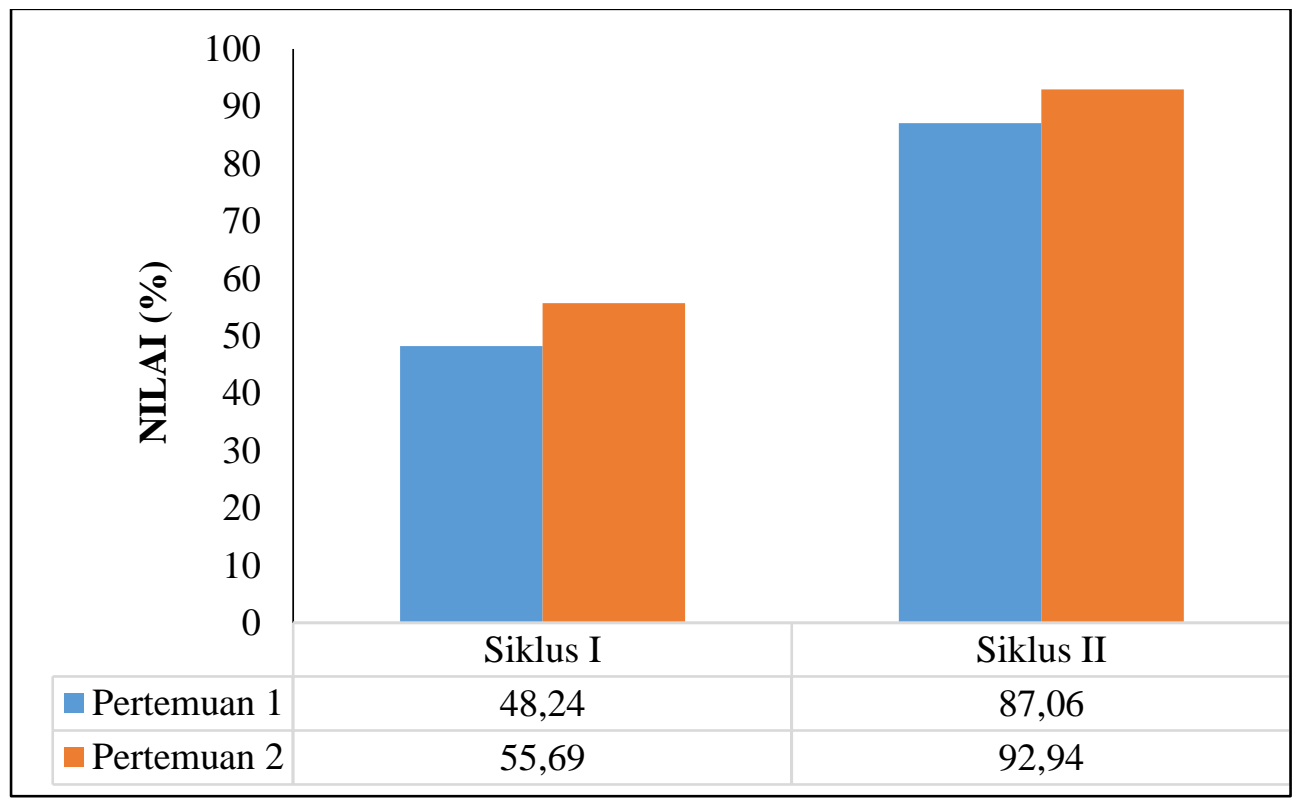

Gambar 2. Hasil Observasi Aktivitas Belajar Pesrta Didik

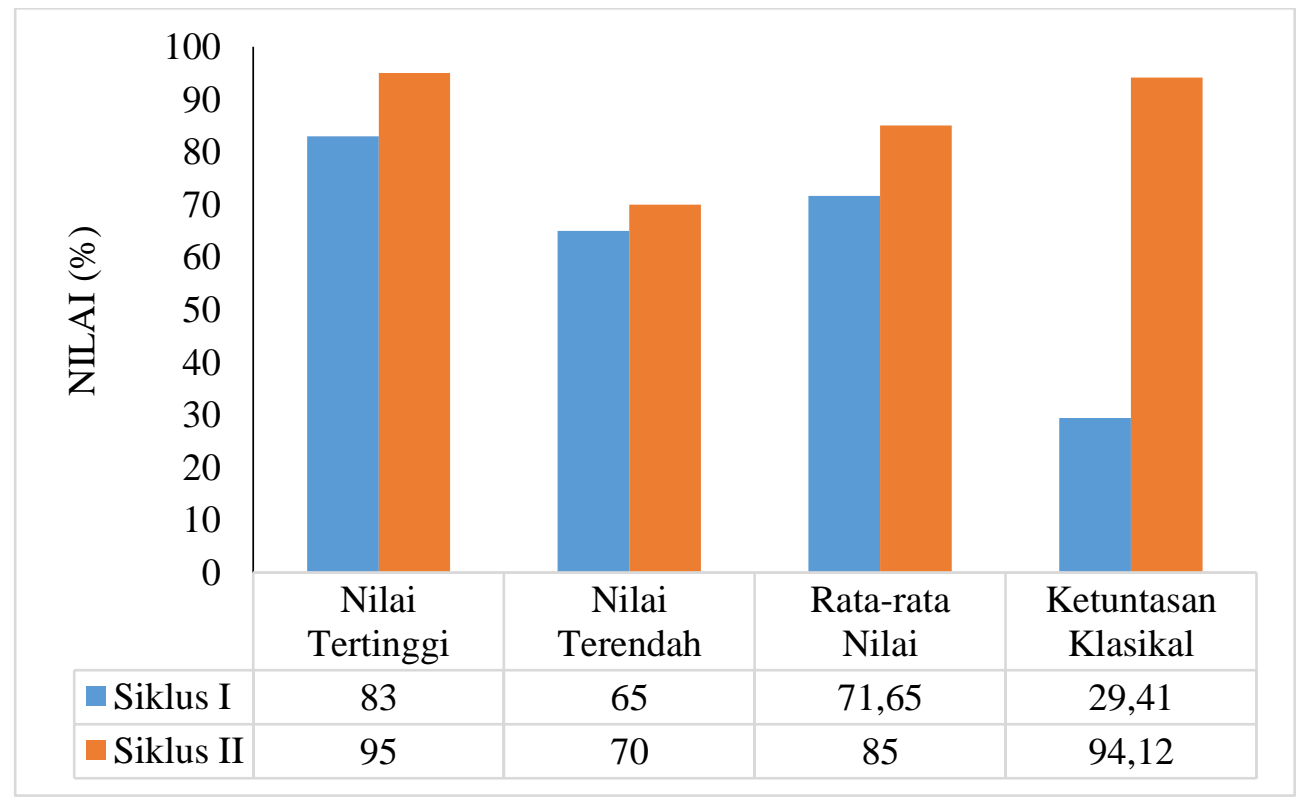

Gambar 3. Hasil Belajar Peserta Didik Pada Siklus I dan Siklus II 
Aktivitas peserta didik selama proses pembelajaran merupakan salah satu indikator adanya keinginan peserta didik untuk belajar. Aktivitas peserta didik di dalam proses pembelajaran dapat mendukung terciptanya situasi belajar aktif. Adanya aktivitas mengajukan dan menjawab pertanyaan dapat membantu peserta didik untuk mengali semua aspek materi yang sudah dipelajarinya baik yang sudah dimengerti ataupun yang belum dimengerti. Dengan peserta didik bertanya, maka peserta didik akan mendapat jawaban dari kesulitannya. Demikian juga dengan sumber belajar, peserta didik yang memiliki sumber belajar terlihat kesiapannya dalam menghadapi pembelajaran. Peserta didik yang tidak memiliki sumber belajar akan mengalami kesulitan dalam menjawab pertanyaan yang ada di dalam teka teki silang, hal ini terlihat pada siklus I dimana peserta didik lebih banyak mencoba meminjam sumber belajar teman sehingga dalam menyelesaikan teka teki silang menjadi lebih lama. Aktivitas peserta didik dalam kelompok, memperlihatkan bahwa peserta didik sudah bisa merespon teman jika ada peserta didik yang lain mengajukan pertanyaan. Dan kerjasama kelompok peserta didik juga sangat baik, karena dalam mengisi teka teki silang peserta didik sangat antusias.

Pembelajaran yang dikemas dalam bentuk permainan dapat merangsang daya pikir peserta didik kelas XII.2. Penggunaan media teka teki silang tidak hanya memberikan aktifitas tambahan untuk bergembira semata, tetapi dapat dijadikan pembelajaran dan pengajaran yang bertujuan memberikan kesempatan kepada peserta didik untuk lebih berkonsentrasi dalam memecahkan masalah yang ada di materi pembelarajaran kontrol proses (Atiyah, Untari, \& Tsalatsa, 2019). Penggunaan media yang tepat pada proses pembelajaran dapat menciptakan hubungan belajar yang lebih fleksibel antar peserta didik dan guru serta melatih berbagai kecakapan berpikir peserta didik untuk meningkatkan hasil belajar yang lebih baik (Putra, Agung, \& Sulastri, 2014). Penggunaan media teka teki silang efektif mampu mengubah dinamika kelas dan menciptakan kemauan yang lebih besar untuk belajar dan bersikap (Rosady, Lisa, \& Supiandi, 2018).

Selama proses pembelajaran di kelas XII.2 group A, peserta didik seringkali mengalami macet dalam mengisi teka teki silang dan beberapa pertanyaan tidak dapat 
dijawab. Hal tersebut bukan merupakan kekurangan, justru dengan hal itu peserta didik akan lebih terpacu dan tertantang untuk mencari jawaban pertanyaan dalam teka teki silang dengan bertanya kepada teman. Hal ini akan mendorong peserta didik lebih bereksplorasi dalam proses pembelajaran dan memancing peserta didik lebih aktif di dalam kelas .

Hasil observasi pada siklus II menunjukkan adanya peningkatan aktivitas dan hasil belajar peserta didik. Hal tersebut terlihat dari aktivitas, ketuntasan klasikal, dan nilai rata-rata kelas peserta didik sudah mencapai target penelitian karena didukung oleh beberapa faktor. Pada siklus II guru lebih dapat menyampaikan proses pembelajaran denagn media teka teki silang kepada peserta didik dengan baik, sehingga guru dan peserta didik lebih nyaman dalam melaksanakan kegiatan pembelajaran di siklus II.

Aktivitas menjadi salah satu faktor yang mempengaruhi hasil belajar peserta didik. Aktivitas merupakan prinsip yang sangat penting dalam interaksi belajar mengajar. Situasi belajar aktif dapat merangsang peserta didik untuk lebih eksplor dalam proses pembelajaran yang dapat meningkatkan hasil belajarnya (Angraini, Rahmi, \& Delyana, 2019). Dengan demikian peningkatan aktivitas peserta didik akan berjalan bersamaan dengan peningkatan hasil belajar peserta didik di dalam kelas (Rosmilasari, Sujana, \& Wiarta, 2014). Penggunaan media ini sangat efektif untuk melatih konsentrasi siswa. Dengan mengisi kotak- kotak sesuai dengan jawaban dari pertanyaan yang telah disediakan dapat menghasilkan daya ingat yang tajam dan tingkat pemahaman siswa yang lebih (Wana, 2021)

Pembelajaran dengan menggunakan media teka teki silang dapat dijadikan suatu alternatif untuk meningkatkan hasil belajar dan aktivitas peserta didik sehingga proses pembelajaran dapat berlangsung dengan baik dan optimal. Penggunaan media pembelajaran teka teki silang dapat menignkatkan aktivitas dan hasil belajar peserta didik kelas XII.2 Sekolah Menengah Kejuruan SMTI Padang pada meta pelajaran Kontrol Proses.

Edusaintek: Jurnal Pendidikan, Sains dan Teknologi Vol. 8 (1) 2021 | 48 


\section{SIMPULAN}

Berdasarkan hasil penelitan yang dilaksnakan, dapat disimpulkan bahwa pemanfaatan media Teka Teki Silang(TTS) dalam proses pembelajaran Kontrol Proses dapat meningkatkan aktivitas belajar peserta didik kelas XII.2 di Sekolah Menengah kejuruan SMTI Padang. Hal ini ditunjukkan adanya peningkatan persentase keaktifan peserta didik dari siklus I sebesar 55,69\% menjadi 92,94\% pada siklus II. Secara klasikal jumlah peserta didik yang tuntas SKM pada siklus I sebebsar 29,41\% dan mengalami peningkatan pada siklus II menjadi 94,12\%. Nilai rata-rata kelas mengalami peningkatan sebesar 13,35\%. Dalam proses pembelajaran siswa dapat mengembangkan daya pikir siswa dalam memahami pelajaran Kontrol Proses dan meningkatkan minat peserta didik dalam mendalami mata pelajaran.

\section{DAFTAR RUJUKAN}

Angraini, T. W. P., Rahmi, \& Delyana, H. (2019). PENGARUH PENERAPAN

MODEL DISCOVERY LEARNING DISERTAI STRATEGI

PEMBELAJARAN AKTIF TIPE TEKA-TEKI SILANG TERHADAP HASIL BELAJAR SISWA KELAS VII. JES-MAT, 5(1), 54-62.

https://doi.org/https://doi.org/10.25134/jes-mat.v5i1.1744

Atiyah, U., Untari, M. F. A., \& Tsalatsa, A. N. (2019). Keefektifan Model

Pembelajaran Numbered Head Together (NHT) Dengan Media Teka-Teki

Silang Terhadap Hasil Belajar Tematik Siswa. International Journal of

Elementary Education, 3(1), 46. https://doi.org/10.23887/ijee.v3i1.17284

Awal, R., \& Sari, D. (2019). PENGARUH MODEL PEMBELAJARAN GALLERY

WALK BERBANTUAN TEKA-TEKI SILANG TERHADAP HASIL

BELAJAR SISWA. Bio-Lectura: Jurnal Pendidikan Biologi, 6(2), 172-182.

https://doi.org/https://doi.org/10.31849/bl.v6i2.3573

Lakoro, S., Eraku, S., \& Yusuf, D. (2020). Pengaruh Media Permainan Teka-Teki

Silang Terhadap Hasil Belajar Siswa Pada Pembelajaran Geografi Di Sma

Negeri 1 Marisa. Jambura Geo Education Journal, 1(1), 32-38.

https://doi.org/10.34312/jgej.v1i1.4845

Meileni, N. K., Tastra, I. D. K., \& Riastini, P. N. (2017). Pengaruh Model 
Pembelajaran Talking Stick Berbantuan Media Question Box Terhadap Hasil Belajar Ipa Kelas V. Journal of Education Technology, 1(3), 183. https://doi.org/10.23887/jet.v1i3.12503

Nafi', A., \& Sulistiyo, E. (2013). Pengaruh Pembelajaran Aktif Dengan Strategi Teka-Teki Silang Terhadap Hasil Belajar Siswa Pada Standar Kompetensi Melakukan Install Home Theater Di Smk Negeri 2 Surabaya. Jurnal Pendidikan Teknik Elektro, 3(1), 37-45. https://doi.org/https://doi.org/10.34312/jgej.v1i1.4845

Putra, P. A., Agung, A. A. G., \& Sulastri, N. M. (2014). PENGARUH MODEL PEMBELAJARAN SCRAMBLE BERBANTUAN MEDIA PERMAINAN TEKA-TEKI SILANG TERHADAP HASIL BELAJAR BAHASA INDONESIA SISWA KELAS V SD NEGERI 1 SANGSIT Universitas Pendidikan Ganesha. Jurnal Mimbar PGSD Universitas Pendidikan Ganesha, 2(1), 1-12.

Rosady, F., Lisa, Y., \& Supiandi, M. I. (2018). Pengaruh Model Pembelajaran Teams Game Tournament (Tgt) Berbasis Teka-Teki Silang Terhadap Hasil Belajar Kognitif Siswa Pada Materi Sistem Pencernaan Di Kelas Viii Sekolah Menengah Pertama Negeri 2 Kelam Permai Tahun Pelajaran 2016/2017. JPBIO (Jurnal Pendidikan Biologi), 2(1), 9-17. https://doi.org/10.31932/jpbio.v1i1.207

Rosmilasari, D. M. A. R., Sujana, I. W., \& Wiarta, I. wayan. (2014). Ada Pengaruh Penerapan Model Pembelajaran Mid Berbantuan Media Teka Teki Silang Dan Siswa Kelas V Sd Gugus Untung Surapati Denpasar Timur. Jurnal Mimbar PGSD Universitas Pendidikan Ganesha, 2(1), 1-12.

Wana, P. R. (2021). Pengaruh Penggunaan Media Teka-Teki Silang (TTS) Terhadap Hasil Belajar Siswa pada Pelajaran IPS Kelas V. Jurnal Pendidikan Modern, 6(2), 100-107. https://doi.org/10.37471/jpm.v6i2.207

Zein, M. (2016). Peran Guru dalam Pengembangan Pembelajaran. Jurnal Inspiratif Pendidikan, 5(2), 274-285. Retrieved from http://103.55.216.56/index.php/Inspiratif-Pendidikan/article/view/3480 